International Journal of Health Sciences
Available online at www.sciencescholar.us
Vol. 5 No. 2, August 2021, pages: $62-70$
e-ISSN: 2550-696X, p-ISSN: $2550-6978$
https://doi.org/10.29332/ijhs.v5n2.1199

\title{
Differences of Heparin Binding Protein Levels in Preeclampsian and Non Preeclampsian Women
}

\author{
Nurrahma Layuk ${ }^{\text {a }}$, Sitti Wahyuni ${ }^{\mathrm{b}}$, Sharvianty Arifuddin c \\ Manuscript submitted: 09 March 2021, Manuscript revised: 27 April 2021, Accepted for publication: 18 May 2021
}

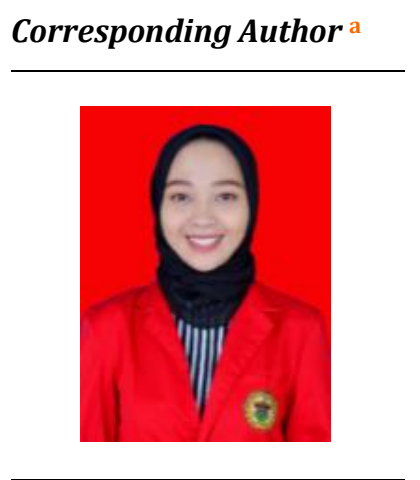

Keywords

heparin-binding protein; urinary tract infection; preeclampsia;

\begin{abstract}
This study aims to the incidence of preeclampsia and determine differences in heparin-binding protein levels in preeclamptic and non-preeclamptic mothers and determine the relationship between urinary tract infections in pregnancy. The research design was cross-sectional on 65 respondents with an accidental sampling technique. The research data were obtained from a questionnaire containing a list of questions given to respondents, measurement of middle urine samples to measure nitrite, leukocytes urine using dipstick method, and to determine heparin-binding protein (HBP) levels using the ELISA method in the Hasanuddin University RSP Research Laboratory. The results of the study found there was a difference in the levels of heparin-binding protein in pregnant women without preeclampsia, namely $1.90 \pm 0.22 \mathrm{Ng} / \mathrm{ml}$ and $\mathrm{HBP}$ levels in pregnant women preeclampsia ie $2.39 \pm 0.3 \mathrm{Ng} / \mathrm{ml}$. That there was no significant relationship between urinary tract infections (UTI) and the incidence of preeclampsia with $\mathrm{p}=0.074$. The conclusion in this study is that the levels of heparin-binding protein differ in preeclamptic and nonpreeclamptic mothers, the increase in HBP levels in preeclampsia is due to inflammation, the cause is not through UTI. There is no association between urinary tract infections in pregnant women and the incidence of preeclampsia.
\end{abstract}

International Journal of Health Sciences (C) 2021. This is an open access article under the CC BY-NC-ND license (https://creativecommons.org/licenses/by-nc-nd/4.0/).

\section{Contents}

Abstract.

1 Introduction.

作

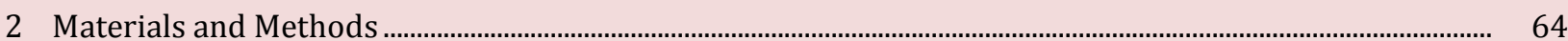

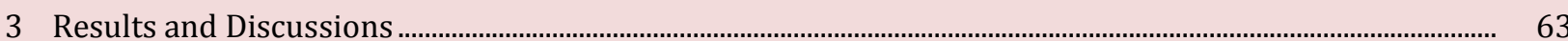

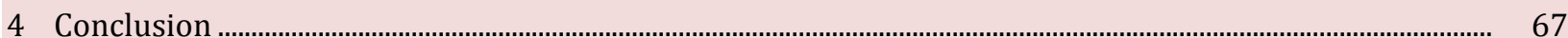

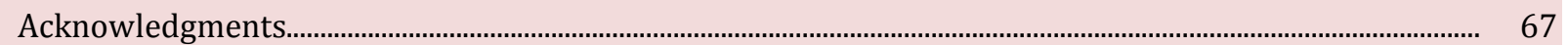

a Midwifery Postgraduate School, Hasanuddin University, Indonesia

b Department of Parasitology, Faculty of Medicine, Hasanuddin University, Indonesia

c Department of Obstetrics and Gynecology, Faculty of Medicine, Hasanuddin University, Indonesia 


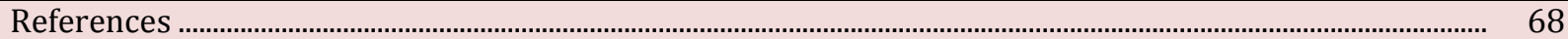

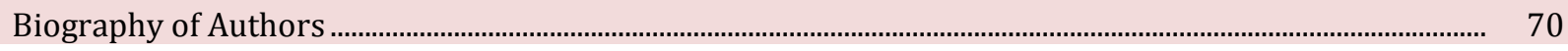

\section{Introduction}

Globally, the maternal mortality rate throughout 2017 was around 800 women who died due to complications during pregnancy and childbirth (World Health Organization, 2018)The maternal mortality rate in Indonesia reaches 177 per 100,000 live births (World Health Organization, 2018). Maternal mortality in Kendari City in 2017 was generally due to hypertension in pregnancy and within 4 years of maternal death, 75 mothers died (Dinkes Sultra, 2017). The main complications that cause maternal mortality are postpartum hemorrhage, infection, high blood pressure during pregnancy (preeclampsia and eclampsia), complications of delivery, and unsafe abortion (World Health Organization, 2018).

Globally, maternal mortality due to eclampsia is around 50,000 cases each year (World Health Organization, 2018). Maternal mortality in Indonesia due to preeclampsia reaches $26.57 \%$ of 100,000 live births (Kemenkes, 2018). Based on the results of the medical records of the Southeast Sulawesi Provincial Hospital from January to 31 October 2019, there were 83 pregnant women with preeclampsia and there were 6 maternal deaths due to preeclampsia/eclampsia.

Preeclampsia is a multisystem disorder with blood pressure greater than 140/90 $\mathrm{mmHg}$ and accompanied by urine protein occurring after 20 weeks of gestation or shortly after delivery (ACOG, 2020). The inflammatory response plays an important role in the initiation and increase of uteroplacental atherosis so that infections that increase systemic inflammation can increase the risk of preeclampsia (Yan et al., 2018; Tranquilli, 2013; Saftlas et al., 2000).

Infections that are often experienced during pregnancy are urinary tract infections (Minassian et al., 2013). Urinary tract infections have the potential to cause the activation of a systemic inflammatory response leading to placental hypoxia, uteroplacental atherosis, endothelial dysfunction, and ultimately preeclampsia and eclampsia (Yan et al., 2018; Sattar et al., 1997; Pinto et al., 2017).

The results of a study conducted in England found that infection in pregnancy can increase the risk of preeclampsia and eclampsia (Minassian et al., 2013). Another study conducted in Tanzania in 2019 found that the link between urinary tract infections and preeclampsia was evidenced by high bacteriuria in pregnant women with preeclampsia and eclampsia compared to pregnant women without preeclampsia and eclampsia. (Kaduma et al., 2019).

Heparin-binding protein is an anti-microbial protein derived from the polymorphonuclear leukocyte (PMN) family and is the only PMN granule protein stored in two different compartments, namely in secretory vesicles and azurophilic granules of neutrophils (Honore et al., 2019). A heparin-binding protein released due to neutrophil activation that undergoes chemotaxis will result in increased release of cytokines in monocytes (increased phagocytosis, and adhesion to endothelium) (Fisher \& Linder, 2017). Monocytes that eventually cross the endothelium and undergo extravasation will differentiate into macrophages that migrate to the site of inflammation (Honore et al., 2019).

The release of heparin-binding protein also affects other cell types such as inducing migration of fibroblasts which play a role in inflammatory responses as well as inducing migration of smooth muscle cells and increasing expression of ICAM1 cells, migration of corneal epithelial cells, and heparin-binding protein also inducing activation of IL- 6 in the epithelial cells of the proximal tubule of the kidney. Thus HBP is a biomarker in predicting organ dysfunction due to bacterial infection and is an important multifunctional inflammatory mediator (Fisher \& Linder, 2017). Based on the above background, the researchers aimed to identify the relationship between preeclampsia and the incidence of infection in pregnancy by analyzing the levels of heparin-binding protein in pregnant women (Merenmies et al., 1991; Wu et al., 1991; Voss et al., 2013; Kett et al., 2003).

Layuk, N., Wahyuni, S., \& Arifuddin, S. (2021). Differences of heparin binding protein levels in preeclampsian and non preeclampsian women. International Journal of Health Sciences, 5(2), 62-70. https://doi.org/10.29332/ijhs.v5n2.1199 


\section{Materials and Methods}

This study used a cross-sectional study method using the chi-square statistical test to see the association of urinary tract infection with preeclampsia and the Mann-Whitney test to measure HBP levels in preeclamptic mothers (Foxman et al., 2000; Ronald, 2003; Sefton, 2000). The place where this research was conducted was the Lepo-Lepo Health Center, the Aliyah Hospital, Kendari City, and the Hasanuddin University Hospital Research Laboratory with a total sample of 65 respondents consisting of 40 respondents with preeclampsia and 25 respondents without preeclampsia. The instrument used in this study was a questionnaire, measurement of urinary leukocytes and urine nitrites using the dip-dip method with the verify brand, urine centrifugation was carried out at Lepo-Lepo Health Center, and measurement of HBP (Heparin Binding Protein) levels using ELISA (Enzyme-Linked Immunosorbent Assay) at conducted at the Hasanuddin University RSP Research Laboratory Unit.

\section{Results and Discussions}

Table 1

Distribution of sample characteristics

Characteristics of respondents based on age, gravida, symptoms of UTI, urinary nitrite, and urinary leukocytes

\begin{tabular}{|c|c|c|c|c|c|}
\hline \multirow{3}{*}{ Categories } & & \multicolumn{2}{|c|}{ Preeclampsia Status } & \multirow{3}{*}{$\begin{array}{l}\text { Total } \\
\mathrm{n}=65(\%)\end{array}$} & \multirow{3}{*}{ P-value } \\
\hline & & Yes & Today & & \\
\hline & & & & & \\
\hline \multirow[t]{2}{*}{ Age } & $<20$ or $>35$ th & $15(75.0 \%)$ & $5(25.0 \%)$ & $20(100 \%)$ & \multirow{2}{*}{0,173} \\
\hline & $20-35^{\text {th }}$ & $25(55.6 \%)$ & $20(44,4 \%)$ & $45(100 \%)$ & \\
\hline \multirow[t]{2}{*}{ Gravida } & primigravida & $16(57.1 \%)$ & $12(42.9 \%)$ & $28(100 \%)$ & \multirow{2}{*}{0,610} \\
\hline & multigravida & $24(65 \%)$ & $13(35 \%)$ & $34(100 \%)$ & \\
\hline \multirow{2}{*}{ Gestational } & 20-27 week & $20(59 \%)$ & $14(41 \%)$ & $34(100 \%)$ & \multirow{3}{*}{0.799} \\
\hline & $>28$ week & $20(65 \%)$ & $11(35 \%)$ & $31(100 \%)$ & \\
\hline \multirow[t]{3}{*}{ Nitrit } & Positifve2 & $2(100 \%)$ & 0 & $2(100 \%)$ & \\
\hline & Positifve1 & $20(95 \%)$ & $1(5 \%)$ & $21(100 \%)$ & \multirow[t]{2}{*}{$<0.001$} \\
\hline & Negative & $24(57 \%)$ & $18(43 \%)$ & $42(100 \%)$ & \\
\hline \multirow[t]{4}{*}{ Leucosit } & Positifve2 & $4(100 \%)$ & 0 & $4(100 \%)$ & \multirow{4}{*}{$<0.001$} \\
\hline & Positifve1 & $27(87 \%)$ & $4(3 \%)$ & $31(100 \%)$ & \\
\hline & plus neg & $9(50 \%)$ & $9(50 \%)$ & $18(100 \%)$ & \\
\hline & Negative & 0 & $12(100 \%)$ & $12(100 \%)$ & \\
\hline \multirow[t]{2}{*}{ Symptoms of UTI } & Yes & $30(90.9 \%)$ & $3(9.1 \%)$ & $33(100 \%)$ & \multirow{2}{*}{$<0.001$} \\
\hline & No & $10(31.3 \%)$ & $22(68.7 \%)$ & $32(100 \%)$ & \\
\hline
\end{tabular}

Source: Primary data, 2021

Table 1 shows that between the preeclampsia and non-preeclamptic groups, there were no significant differences in the categories of maternal age, gravida, and gestational age. However, nitrite levels, urinary leukocytes, and urinary tract infection symptoms differed between those with preeclampsia.

Table 2

Comparison of mean HBP levels in urinary tract infection and non -urinary tract infection

\begin{tabular}{llcl}
\hline \multirow{2}{*}{ Variable } & \multicolumn{2}{c}{ median (min-max) } & p-value* \\
\cline { 2 - 3 } & UTI $(\mathrm{n}=6)$ & Not UTI $(\mathrm{n}=59)$ & 0.415 \\
\hline HBP $(\mathrm{ng} / \mathrm{ml})$ & $2.40(1.92-2.55)$ & $2.15(1.20-3.05)$ & \\
\hline
\end{tabular}




\section{Uji Mann-Whitney}

Table 2, based on the table above, the results with a value of $\mathrm{P}=0.415$, meaning that there is no significant difference in HBP levels in pregnant women with urinary tract infections and pregnant women without UTIs. The min-max HBP in women with UTI is 2:40 (1.92-2.55), whereas in women without UTI is 2:15 (1:20 to $3: 05) \mathrm{ng} / \mathrm{ml}$.

Table 3

Comparison of mean HBP levels preeclamptic and non-preeclamptic mothers

\begin{tabular}{|c|c|c|c|}
\hline \multirow{2}{*}{ Variable } & \multicolumn{2}{|c|}{ median (min-max) } & \multirow[b]{2}{*}{$p$-value } \\
\hline & Preeclampsia $(n=40)$ & Not Preeclampsia $(n=25)$ & \\
\hline $\mathrm{HBP}(\mathrm{ng} / \mathrm{ml})$ & $2.42(1.55-3.0)$ & $1.91(1.20-2.22)$ & $<0.001$ \\
\hline
\end{tabular}

\section{Uji Mann-Whitney}

Table 3 shows the data after the Mann-Whitney test on HBP levels between pregnant women with preeclampsia and pregnant women without preeclampsia, the value of $p=<0.001$, where $p<0.05$, which means there is a significant difference in HBP levels in pregnant women with preeclampsia and mothers. Pregnant without preeclampsia. The mean value shows higher HBP levels in pregnant women with preeclampsia compared to pregnant women without preeclampsia.

Table 4

Relationship between urinary nitrites, urinary leukocytes and the incidence of preeclampsia

\begin{tabular}{|c|c|c|c|c|c|}
\hline & & \multicolumn{2}{|c|}{ Preeclampsia Categories } & \multirow[t]{2}{*}{ Total } & \multirow[t]{2}{*}{ P-value } \\
\hline & & $\begin{array}{l}\text { Yes } \\
N=40(61.5 \%)\end{array}$ & $\begin{array}{l}\text { Today } \\
\mathrm{N}=25(38.5 \%)\end{array}$ & & \\
\hline \multirow{2}{*}{$\begin{array}{l}\text { Urinary tract } \\
\text { infection }\end{array}$} & Yes & $6(100 \%)$ & 0 & 6 & \multirow[t]{2}{*}{0.074} \\
\hline & & $34(57.6 \%)$ & $25(42.4 \%)$ & 59 & \\
\hline
\end{tabular}

*Uji chi-square

Table 4 shows the results of the analysis test to determine the association of urinary tract infections in pregnant women with the incidence of preeclampsia with diagnosis based on urinary nitrite and urinary leukocytes $>+1$ obtained p 0.074 , which means that there is no significant relationship between urinary tract infections in pregnant women and the incidence of preeclampsia.

\section{Discussion}

The results found that respondents with preeclampsia were dominant at the age of 20-35 years, where the age range was not a risk factor for preeclampsia. The statistical test results also found the value of $P=0.173$, which means there is no significant relationship between variables. Maternal age $>35$ years has a high risk of developing chronic hypertension in pregnancy, increasing maternal age indicating the need for more efforts for better blood pressure control before and during pregnancy as maternal age is strongly associated with increased vascular disease (Ananth et al., 2019). Pregnant women aged less than 20 years are at risk of developing preeclampsia due to failure of trophoblast invasion, which causes maladaptation that triggers the development of preeclampsia (Kumari et al., 2016). Research conducted in America with results $\mathrm{P}=0.23$ where $>0.05$ means there is no significant relationship between the variables age and preeclampsia (Victoria et al., 2021).

In the gravida characteristics, it was found that the dominant respondents were in the multigravida group. There were 34 respondents with multigravida who experienced preeclampsia and 28 respondents for

Layuk, N., Wahyuni, S., \& Arifuddin, S. (2021). Differences of heparin binding protein levels in preeclampsian and non preeclampsian women. International Journal of Health Sciences, 5(2), 62-70. https://doi.org/10.29332/ijhs.v5n2.1199 
primigravida. Preeclampsia that occurs in multigravida pregnant women is mostly caused by parity at risk and age at risk. High parity ( $>3$ times childbirth) is a risk of preeclampsia due to a decrease in the function of the reproductive system and/or because the mother is busy taking care of the household and causes fatigue so that the mother is unable to meet her nutritional needs. Another study conducted in coastal Africa found a result of $p=0.088$ where the dominant group of preeclamptic pregnant women was in the multiparous and grand multipara group, not in the primigravida group (Machano \& Joho, 2020).

In the characteristics of gestational age, it was found that high blood pressure experienced by pregnant women was true preeclampsia because all gestational ages were $>20$ weeks. 34 mothers were in the second trimester of gestation, 31 women were in the third trimester of pregnancy and none of the respondents in this study had a posterior gestational age ( $>40$ weeks). In women who have had a history of hypertension or preeclampsia before 34 weeks, it is recommended that they always carry out regular antenatal examinations to reduce the incidence of recurrent risk in the following week (Webster et al., 2019). A meta-analysis study conducted by Johnson et all suggested that hypertension occurring at $<20$ weeks of gestation can increase the risk of preeclampsia in the next trimester 5.43 times (Johnson et al., 2020).

Heparin-binding protein is a pro-inflammatory protein that is a biomarker in predicting organ dysfunction due to bacterial infection and is an important multifunctional inflammatory mediator (Fisher \& Linder, 2017). Withdrawal of the diagnosis of urinary tract infections in pregnant women with UTI based on the results of measurements of urinary leukocytes and urinary nitrin $>+1$. In this study, the researchers did not get a difference in HBP levels between pregnant women with isk and without with a P-value of 0.415 , perhaps because the population of pregnant women with UTI is very small and not many have preeclampsia (6 pregnant women who experienced isk and also experienced preeclampsia). Comparison of HBP levels between pregnant women with UTI $2.40 \mathrm{ng} / \mathrm{ml}$ (min-max: 1.92-2.55 ng / ml) and pregnant women without UTI $2.51 \mathrm{ng} / \mathrm{ml}$ (min-max: $1.20-3.05 \mathrm{ng} / \mathrm{ml}$ ).

Preeclampsia is caused by the disruption of the invasion of the trophoblast tissue from the spiral arteries which fails the conversion of high resistance blood vessels to low resistance vessels leading to impaired placental perfusion and leading to placental ischemia (Gomaa et al., 2015). The placenta that experiences ischemia and hypoxia will produce free radicals (very toxic hydroxyl radicals), causing oxidative stress. Oxidative stress can trigger the release of pro-inflammatory responses and release of cytokines such as TNF- $\alpha$, IL-6, IL-2, which can trigger complement activation, stimulate the synthesis of antiangiogenic factors: soluble fms-like tyrosine kinase-1 (sFlt-1) and soluble. endoglin (sEng), and reduces the production of placental growth factor (PLGF) (Mirkovic et al., 2018). Heparin-binding protein is a pro-inflammatory protein that plays a role in predicting organ dysfunction due to infection and is a multi-functional inflammatory mediator (Fisher \& Linder, 2017). HBP plays a role in increasing the contraction effect of endothelial cells which increases blood vessel permeability, increases the ability of binding to endotoxins, endotosis HBP by monocytes can stimulate lipopolysaccharide-induced tumor necrosis factor- $\alpha$ (tnf-alpha plays an important role in the pathogenesis of preeclampsia) and its ability to attract monocytes to the site of inflammation (Olczak \& Watorek, 2002). Heparin-binding protein is immediately released due to the activation of neutrophils that undergo chemotaxis, the effect of HBP on white blood cells, especially on monocytes, namely increasing the release of cytokines, increasing phagocytosis, and adhesion to the endothelium (5). Heparinbinding protein also induces migration of smooth muscle cells and increases expression of ICAM1 cells, migration of corneal epithelial cells, and heparin-binding protein also induces the activation of IL-6 production where we know that IL-6 is an important cytokine that is closely related to the pathogenesis of preeclampsia (Fisher \& Linder, 2017; Wang et al., 2021). In this study, we found the results of the analysis $\mathrm{P}=$ $<0.001$, which means that there is a difference between the levels of heparin-binding protein in preeclamptic and non-preeclamptic mothers. The value of HBP levels in pregnant women without preeclampsia is 1.91 $\mathrm{ng} / \mathrm{ml}$ (minimum-maximum: $1.20-2.22 \mathrm{ng} / \mathrm{ml}$ ) and HBP levels in preeclamptic pregnant women is $2.42 \mathrm{ng} / \mathrm{ml}$ (minimum-maximum: $1.55-3.0 \mathrm{ng} / \mathrm{ml}$ ).

Urinary tract infection is an infection that often occurs in pregnancy and usually occurs around week 6 and then peaks at week 22-24 due to changes in the physiological adaptation of increased plasma volume which causes a decrease in urine concentration which can facilitate the development of bacteria (Michelim et al., 2016). Another study conducted by Rejali and Ahmadi stated that there was no significant relationship between maternal UTI and the incidence of preeclampsia. The p-value of preeclampsia and UTI is 0.282 which indicates that there is no significant relationship between these variables (Rejali \& Ahmadi, 2019). In this 
study, the results found $\mathrm{P}=0.074$, which means there is no significant relationship between urinary tract infections in pregnant women and preeclampsia. UTI diagnosis was obtained from the results of anamesis using a questionnaire and examination of urinary leukocytes and nitrites $(>+1)$ with a total of 6 preeclamptic pregnant women who were ISK and 59 preeclamptic pregnant women without UTI.

\section{Conclusion}

The results Based on the results of research and analysis of information about the factors that trigger the incidence of preeclampsia, it can be concluded the median HBP levels were higher in mothers with preeclampsia. The increase in HBP levels in preeclampsia is due to inflammation, the cause is not through UTI. There is no relationship between urinary tract infection and the incidence of preeclampsia.

\section{Acknowledgments}

The completion of this research cannot be separated from the support of various parties. Researchers specifically express their deepest gratitude to the Director Aliyah Hospital Puskesmas Lepo-lepo Kendari, All Respondents and the people of Kendari city, and all those who have helped, provide suggestions and input as well as an encouragement both moral and material in nature.

Layuk, N., Wahyuni, S., \& Arifuddin, S. (2021). Differences of heparin binding protein levels in preeclampsian and non preeclampsian women. International Journal of Health Sciences, 5(2), 62-70. https://doi.org/10.29332/ijhs.v5n2.1199 


\section{References}

ACOG. (2020). Preeclampsia and Pregnancy. Obstetrics and Gynecology.

Ananth, C. V., Duzyj, C. M., Yadava, S., Schwebel, M., Tita, A. T., \& Joseph, K. S. (2019). Changes in the prevalence of chronic hypertension in pregnancy, United States, 1970 to 2010. Hypertension, 74(5), 1089-1095.

Dinkes Sultra. (2017). Profil Kesehatan Propinsi Sulawesi Tenggara 2016. Dinas Kesehatan Provinsi Sulawesi Tenggara.

Fisher, J., \& Linder, A. (2017). Heparin-binding protein: a key player in the pathophysiology of organ dysfunction in sepsis. Journal of internal medicine, 281(6), 562-574.

Foxman, B., Barlow, R., D'Arcy, H., Gillespie, B., \& Sobel, J. D. (2000). Urinary tract infection: self-reported incidence and associated costs. Annals of epidemiology, 10(8), 509-515. https://doi.org/10.1016/S10472797(00)00072-7

Gomaa, M. F., Naguib, A. H., Swedan, K. H., \& Abdellatif, S. S. (2015). Serum tumor necrosis factor- $\alpha$ level and uterine artery Doppler indices at 11-13 weeks' gestation for preeclampsia screening in low-risk pregnancies: a prospective observational study. Journal of reproductive immunology, 109, 31-35. https://doi.org/10.1016/j.jri.2015.02.007

Honore, P. M., De Bels, D., Gutierrez, L. B., Redant, S., \& Spapen, H. D. (2019). Heparin-binding protein in sepsis: player! predictor! positioning?.

Johnson, S., Liu, B., Kalafat, E., Thilaganathan, B., \& Khalil, A. (2020). Maternal and perinatal outcomes of white coat hypertension during pregnancy: a systematic review and meta-analysis. Hypertension, 76(1), 157-166.

Kaduma, J., Seni, J., Chuma, C., Kirita, R., Mujuni, F., Mushi, M. F., ... \& Mshana, S. E. (2019). Urinary tract infections and preeclampsia among pregnant women attending two hospitals in Mwanza City, Tanzania: A 1: 2 Matched case-control study. BioMed research international, 2019.

Kemenkes. (2018). Info DATIN (Pusat Data dan Informasi Kementrian RI). Kementerian Kesehatan RI, 1-7.

Kett, W. C., Osmond, R. I., Moe, L., Skett, S. E., Kinnear, B. F., \& Coombe, D. R. (2003). Avidin is a heparin-binding protein. Affinity, specificity and structural analysis. Biochimica et Biophysica Acta (BBA)-General Subjects, 1620(1-3), 225-234. https://doi.org/10.1016/S0304-4165(02)00539-1

Kumari, N., Dash, K., \& Singh, R. (2016). Relationship between Maternal Age and Preeclampsia. IOSR Journal of Dental and Medical Sciences, 15(12), 55-7.

Machano, M. M., \& Joho, A. A. (2020). Prevalence and risk factors associated with severe pre-eclampsia among postpartum women in Zanzibar: a cross-sectional study. BMC Public Health, 20(1), 1-10.

Merenmies, J., Pihlaskari, R., Laitinen, J., Wartiovaara, J., \& Rauvala, H. (1991). 30-kDa heparin-binding protein of brain (amphoterin) involved in neurite outgrowth. Amino acid sequence and localization in the filopodia of the advancing plasma membrane. Journal of Biological Chemistry, 266(25), 16722-16729. https://doi.org/10.1016/S0021-9258(18)55361-8

Michelim, L., Bosi, G. R., \& Comparsi, E. (2016). Urinary tract infection in pregnancy: review of clinical management. J Clin Nephrol Res, 3(1), 1030.

Minassian, C., Thomas, S. L., Williams, D. J., Campbell, O., \& Smeeth, L. (2013). Acute maternal infection and risk of pre-eclampsia: a population-based case-control study. PloS one, 8(9), e73047.

Mirković, L., Nejković, L., \& Micić, J. (2018). A new pathophysiological concept and new classification of preeclampsia. Vojnosanitetski pregled, 75(1), 83-94.

Olczak, M., \& Wątorek, W. (2002). Structural analysis of $\mathrm{N}$-glycans from human neutrophil azurocidin. Biochemical and biophysical research communications, 293(1), 213-219. https://doi.org/10.1016/S0006-291X(02)00201-2

Pinto, F., Suwiyoga, I. K., Widiana, I. G. R., \& Yasa, I. W. P. S. (2017). Health behavior and status related to mother's death in Timor-Leste. International Research Journal of Engineering, IT and Scientific Research, 3(4), 57-65.

Rejali, M., \& Ahmadi, S. S. (2019). Prevalence and risk factors of urinary tract infection among pregnant women in Shahrekord, Iran. International Journal of Epidemiologic Research, 6(2), 55-59.

Ronald, A. (2003). The etiology of urinary tract infection: traditional and emerging pathogens. Disease- $a$ month, 49(2), 71-82. https://doi.org/10.1067/mda.2003.8

Saftlas, A. F., Wang, W., Risch, H., Woolson, R., Hsu, C. D., \& Bracken, M. B. (2000). Prepregnancy body mass index and gestational weight gain as risk factors for preeclampsia and transient hypertension. Annals of epidemiology, 10(7), 475. https://doi.org/10.1016/S1047-2797(00)00167-8 
Sattar, N., Bendomir, A., Berry, C., Shepherd, J., Greer, I. A., \& Packard, C. J. (1997). Lipoprotein subfraction concentrations in preeclampsia: pathogenic parallels to atherosclerosis. Obstetrics \& Gynecology, 89(3), 403-408. https://doi.org/10.1016/S0029-7844(96)00514-5

Sefton, A. M. (2000). The impact of resistance on the management of urinary tract infections. International journal of antimicrobial agents, 16(4), 489-491. https://doi.org/10.1016/S0924-8579(00)00282-X

Tranquilli, A. L. (2013). Introduction to ISSHP new classification of preeclampsia. Pregnancy Hypertension: An International Journal of Women's Cardiovascular Health, 3(2), 58-59. https://doi.org/10.1016/j.preghy.2013.04.006

Victoria, A., Dreixler, J., Tung, A., Mueller, A., Heimberger, S., Fazal, A. A., Naseem, H., Lang, R., Kruse, E., Yamat, M., Granger, J. P., Bakrania, B. A., Rodriguez-kovacs, J., \& Rana, S. (2021). Long-Term Postpartum Cardiac Function and Its Association With Preeclampsia. Journal of the American Heart Association, 1-9.

Voss, S., Hallström, T., Saleh, M., Burchhardt, G., Pribyl, T., Singh, B., ... \& Hammerschmidt, S. (2013). The choline-binding protein PspC of Streptococcus pneumoniae interacts with the C-terminal heparin-binding domain of vitronectin. Journal of Biological Chemistry,288(22), 15614-15627. https://doi.org/10.1074/jbc.M112.443507

Wang, Y., Gu, Y., Alexander, J. S., \& Lewis, D. F. (2021). Preeclampsia Status Controls Interleukin-6 and Soluble IL-6 Receptor Release from Neutrophils and Endothelial Cells: Relevance to Increased Inflammatory Responses. Pathophysiology, 28(2), 202-211.

Webster, K., Fishburn, S., Maresh, M., Findlay, S. C., \& Chappell, L. C. (2019). Diagnosis and management of hypertension in pregnancy: summary of updated NICE guidance. $B m j, 366$.

World Health Organization. (2018). Global Health Observatory (GHO): Data Repository. GHO. https://www.who.int/gho/maternal_health/en/

Wu, D. Q., Kan, M. K., Sato, G. H., Okamoto, T., \& Sato, J. D. (1991). Characterization and molecular cloning of a putative binding protein for heparin-binding growth factors. Journal of Biological Chemistry, 266(25), 16778-16785. https://doi.org/10.1016/S0021-9258(18)55368-0

Yan, L., Jin, Y., Hang, H., \& Yan, B. (2018). The association between urinary tract infection during pregnancy and preeclampsia: A meta-analysis. Medicine, 97(36).

Layuk, N., Wahyuni, S., \& Arifuddin, S. (2021). Differences of heparin binding protein levels in preeclampsian and non preeclampsian women. International Journal of Health Sciences, 5(2), 62-70. https://doi.org/10.29332/ijhs.v5n2.1199 


\section{Biography of Authors}

\begin{tabular}{l|l|} 
Nurrahma Layuk \\
Completed Diploma IV Midwivery Education in 2018 at the Poltekkes Kemenkes \\
Manado, and is currently studying at Hasanuddin University postgraduate school. \\
Email: nrrlayuk@gmail.com
\end{tabular} \mid $\begin{aligned} & \text { Sitti Wahyuni } \\
& \text { Completed her education in the medical faculty in } 1993 \text { at Hasanuddin University, } \\
& \text { and then completed his doctoral program in } 2006 \text { at Leiden University, The } \\
& \text { Netherlands. Works as head of quality assurance and a permanent lecturer at the } \\
& \text { Hasanuddin University medical faculty. } \\
& \text { Email: sittiwahyuni@gmail.com }\end{aligned}$

